\title{
Gerakan Politik Pendukung Kotak Kosong: Keterlibatan Civil Society dalam Pilkada Kabupaten Pati Tahun 2017
}

\author{
Asita Widyasari, Reyke Anggia Dewi, Viera Ma- \\ yasari Sri Rengganis ${ }^{1}$
}

\begin{abstract}
Abstrak
Artikel ini membahas tentang keterlibatan civil society dalam gerakan politik pendukung kotak kosong, yang dikenal dengan GERAM Pati dalam pilkada kabupaten Pati tahun 2017. Pertanyaan yang ingin dijawab adalah bagaimana cara GERAM Pati berkompetisi untuk memenangkan kotak kosong dalam pilkada kabupaten Pati. Fenomena ini menarik, karena kabupaten Pati merupakan satu-satunya daerah yang memiliki pendukung kotak kosong dan menggugat hasil pilkada ke Mahkamah Konstitusi. Selain itu, perolehan suara kotak kosong di kabupaten Pati adalah sebesar 25,48\% dari total jumlah DPT pilkada Pati tahun 2017 merupakan yang tertinggi dibandingkan dengan sembilan daerah lain yang melaksanakan pilkada dengan calon tunggal. Kerangka pikir yang digunakan adalah peran civil society untuk memenangkan kotak kosong dalam pilkada kabupaten Pati. Tujuan artikel ini adalah untuk menganalisa perumusan regulasi, terkait kotak kosong yang pada praktiknya dilaksanakan secara contested democracy, namun infrastruktur yang dibangun masih uncontested democracy. Metode penelitian yang digunakan adalah kualitatif dengan studi kasus. Pengumpulan data bersumber dari buku, jurnal, regulasi, keputusan badan peradilan, keputusan internal KPU, serta wawancara dengan pihak terkait. Temuannya, upaya GERAM Pati memenangkan kotak kosong melalui kampanye serta mengajukan gugatan ke Mahkamah Konstitusi terkait hasil pilkada mengalami kegagalan. Artikel ini menyimpulkan perlu untuk mengakomodir regulasi terkait keterlibatan civil society dalam kampanye dan penyelesaian sengketa hasil pilkada.
\end{abstract}

Kata Kunci: Pilkada Pati 2017; Civil Society; Kotak Kosong; Contested Democracy; Uncontested Democracy

1 Asita Widyasari, Reyke Anggia Dewi, dan Viera Mayasari Sri Rengganis adalah mahasiswa pascasarjana Departemen Politik dan Pemerintahan, Universitas Gadjah Mada. 


\section{Pendahuluan}

Artikel ini membahas tentang keterlibatan civil society dalam gerakan politik pendukung kotak kosong, yang dikenal dengan Gerakan Masyarakat Pati (GERAM Pati) dalam pilkada kabupaten Pati tahun 2017. Tulisan ini juga menjelaskan bahwa mekanisme kotak kosong merupakan sebuah alternatif agar tetap ada kontestasi dalam pilkada yang hanya memiliki calon tunggal. Pada awalnya, Mahkamah Konstitusi (MK) menolak permohonan dengan mekanisme kotak kosong dan menyetujui adanya mekanisme referendum, yaitu dengan mengisi kolom "setuju" atau "tidak setuju". MK melihat bahwa esensi dari sebuah kontestasi suatu pemilihan tidak boleh terbelenggu oleh minimnya pasangan calon yang mendaftar dalam pilkada dan tidak dapat ditunda.

Pada saat itu, MK tidak sependapat dengan penerapan uncontested elections, seperti yang diterapkan di Amerika Serikat, Inggris, Kanada, dan Singapura yang menerapkan prinsip aklamasi dengan tanpa melibatkan suara rakyat. Dengan demikian, kontestasi diwujudkan ke dalam pilihan setuju dan tidak setuju tersebut. Kemudian pada pilkada serentak tahun 2017, ketentuan mengenai referendum ini diubah dengan aturan bahwa pemilihan satu pasangan calon dilaksanakan dengan menggunakan surat suara yang memuat dua kolom yang terdiri atas satu kolom memuat foto pasangan calon dan satu kolom kosong tidak bergambar. Dari sinilah kemudian, munculah mekanisme penggunaan kotak kosong untuk menampung suara pemilih yang mencoblos kolom kosong yang tidak bergambar tersebut. Sistem ini dirancang untuk melahirkan sebuah kontestasi, namun faktanya kotak kosong sebetulnya adalah sebuah objek yang semu, karena dia bukan peserta pilkada. Penggunaan kotak kosong ini hanya dipersiapkan untuk tetap menjaga adanya kontestasi sebagai syarat demokrasi.

Kajian ini menarik dilakukan karena kabupaten Pati merupakan 
satu-satunya wilayah yang memiliki pendukung kotak kosong dan menggugat hasil pilkada ke Mahkamah Konstitusi. Di wilayah yang melaksanakan pilkada serentak dengan calon tunggal, juga terdapat pendukung kotak kosong. Namun perbedaannya, gerakan kotak kosong di kabupaten Pati memiliki pendukung yang terkonsolidasi dalam upayanya untuk berkompetisi. Selain itu, perolehan suara kotak kosong di kabupaten Pati adalah sebesar 25,48\% dari total jumlah DPT pilkada Pati tahun 2017 merupakan yang tertinggi dibandingkan sembilan daerah lain yang melaksanakan pilkada dengan calon tunggal. Gerakan politik pendukung kotak kosong yang dikenal dengan nama GERAM Pati, juga telah melakukan serangkaian upaya untuk memenangkan kontestasi pilkada kabupaten Pati tahun 2017 dengan melalui kampanye dan sosialisasi.

Kerangka pikir yang digunakan dalam artikel ini adalah peran civil society yang terwujud dalam GERAM Pati untuk memenangkan kotak kosong dalam pilkada kabupaten Pati. Artikel ini juga menganalisa perumusan regulasi terkait kotak kosong yang pada praktiknya dilaksanakan secara contested democracy, namun infrastruktur yang dibangun masih uncontested democracy. Penerapan demokrasi di banyak negara, didominasi oleh konsep demokrasi ala Dahl yang berfokus pada adanya kontestasi dan partisipasi. Kontestasi dan partisipasi inilah yang kemudian melahirkan sebuah mekanisme untuk memilih pemimpin yang disebut dengan pemilihan umum (pemilu). Syarat adanya kontestasi inilah yang melahirkan konsep contested democracy, sehingga fenomena calon tunggal secara teoritis bukanlah sesuatu yang tidak demokratis, karena di dalamnya terdapat poin utama demokrasi, yaitu adanya kontestasi dan partisipasi. Hal ini disebabkan karena meskipun hanya ada satu pasang calon dalam pilkada, proses pemungutan suara harus tetap dilaksanakan karena hak pilih warga negara sudah dijamin dalam konstitusi. Selain itu, elemen kontestasi juga sudah terpenuhi karena pasangan calon tunggal juga harus 
melawan kolom kosong. Namun, semua desain contested democracy ini kemudian melahirkan fenomena yang berkebalikan, dimana seluruh infrastuktur penyelenggaraan pemilu ternyata belum mencerminkan sebuah kontestasi (uncontested), karena hanya menguntungkan salah satu pihak, yaitu pasangan calon yang didukung oleh gabungan partai politik.

Penelitian ini menggunakan perspektif deskriptif didukung dengan metode kualitatif berupa studi kasus. Metode kualitatif dipilih karena metode ini lebih menekankan pada kedalaman data jika dibandingkan dengan metode kuantitatif. Teknik pengumpulan data dilakukan dengan studi dokumentasi (bersifat sekunder) yang bersumber dari buku, jurnal, regulasi, keputusan badan peradilan, dan keputusan internal KPU. Selain itu, dilakukan wawancara dengan informan yang dipilih secara purposive, yaitu pemilihan informan kunci atas dasar subjek yang menguasai permasalahan yang berkaitan dengan judul, permasalahan dan fokus penelitian. ${ }^{2}$ Teknik analisa data dalam penelitian kualitatif adalah proses mencari dan menyusun secara sistematis data yang diperoleh dari hasil wawancara, catatan lapangan, studi dokumentasi dengan cara membuat kategorisasi, menjabarkan dalam unit, memilih mana yang penting, dan membuat kesimpulan.

\section{Review Literatur}

\section{Demokrasi dan Kemunculan Calon Tunggal dalam Pilkada di Indonesia}

Joseph Schumpeter mengemukakan bahwa esensi demokrasi adalah masyarakat memiliki kesempatan untuk menerima atau menolak orang yang akan memimpin atau memerintah mereka. Demokrasi secara sederhana merupakan sebuah mekanisme untuk memilih seorang

2 John W. Creswell. (2015). Penelitan Kualitatif dan Desain Riset, Memilih Di antara Lima Pendekatan, Yogyakarta: Pustaka Pelajar. 
pemimpin politik. Sedangkan kemampuan untuk memilih pemimpin di antara pemimpin-pemimpin politik yang berkontestasi itulah yang disebut dengan demokrasi. ${ }^{3}$ Demokrasi dalam arti sempit, juga diungkapkan oleh Robert Dahl yang berpendapat bahwa ada perbedaan pemaknaan mengenai demokrasi, namun setidaknya ada beberapa kriteria yang sama dan harus dipenuhi oleh sebuah pemerintahan agar seluruh anggotanya memiliki hak yang sama dalam berpartisipasi dan menentukan arah kebijakan. Dahl menyebutkan setidaknya ada lima standar kriteria proses demokrasi, yaitu (1) partisipasi yang efektif; (2) persamaan suara; (3) pemahaman yang jelas; (4) pengawasan terhadap agenda; dan (5) pencakupan orang dewasa, dimana sebagian besar orang dewasa memiliki hak kewarganegaraan. ${ }^{4}$ Dalam konsep ini, sebuah negara dianggap demokratis atau tidak demokratis dapat dinilai dengan menggunakan elemen kompetisi, partisipasi, serta kebebasan di negara tersebut, tidak hanya dalam tataran formal tetapi juga dalam praktik kehidupan politik yang sesungguhnya. Munculnya calon tunggal merupakan sebuah penjabaran konsep demokrasi politik yang harus tetap memiliki kriteria partisipasi dan kompetisi, seperti yang diungkapkan oleh Dahl.

Secara kuantitas, pilkada dengan calon tunggal di Indonesia mengalami kenaikan di setiap periodenya. Di tahun 2015, dari 269 daerah yang melaksanakan pilkada, ada tiga daerah yang memiliki calon tunggal. Kemudian di tahun 2017, dari 101 daerah, ada sembilan daerah yang memiliki calon tunggal. Meningkatnya jumlah pasangan calon tunggal dalam pilkada di Indonesia sesungguhnya menunjukkan kuatnya dominasi petahana dalam kontestasi lima tahunan. Pada tahun 2015, tiga pasangan calon tunggal bupati dan wakil bupati di

3 C. Lay, Ridwan Hanif, \& N. Rohman. (2017). The Rise of Uncontested Elections n Indonesia: Case Studies of Pati and Jayapura. Contemporary Southeast Asia: A Journal of International and Strategic Affairs, Volume 39, Number 3, 427-448.

4 R.A. Dahl. (2001). Perihal Demokrasi: Menjelajahi Teori dan Praktek Demokrasi Secara Singkat. Rahmat Zainuddin (penerj.). Jakarta: Yayasan Obor Indonesia. 
kabupaten Tasikmalaya, kabupaten Timor Tengah Utara merupakan petahana. Sedangkan di kabupaten Blitar, pasangan calon tunggal merupakan wakil bupati petahana periode sebelumnya. Sedangkan di tahun 2017, dari sembilan pasangan calon tunggal, delapan di antaranya merupakan petahana. ${ }^{5}$ Calon yang merupakan petahana memiliki tingkat elektabilitas tinggi serta populer di mata masyarakat sehingga otomatis memiliki keunggulan yang bisa digunakan untuk memenangkan pilkada.

Selanjutnya, Peverill Squire menjelaskan bahwa dalam contoh kasus di Amerika, perpaduan dari modal finansial yang kuat pada calon petahana serta tingkat elektabilitas yang tinggi, memunculkan apa yang dinamakan scare-off effect, yaitu sebuah kondisi dimana kandidat di luar petahana memutuskan untuk tidak ikut berkompetisi karena mereka beranggapan pasti akan kalah. Kasus yang hampir mirip ditemukan oleh John Sidel yang melakukan penelitian di Philipina. Di Philipina, terdapat faktor lain yang mendorong munculnya calon tunggal, yaitu dominasi klan lokal serta munculnya bossism yang dapat menjadikan seorang kandidat tidak tertandingi, memberikan keuntungan dan dominasi pada sumber-sumber politik lokal serta kekuatan ekonomi. ${ }^{6}$

Selain itu, penyebab munculnya calon tunggal juga merupakan efek dari tidak berjalannya mekanisme rekrutmen dan kaderisasi di dalam internal partai, sehingga tidak diperoleh calon-calon alternatif selain petahana. Dalam konteks Indonesia, dengan merujuk pada UndangUndang Nomor 10 Tahun 2016 tentang Pilkada, pemilihan yang hanya diikuti satu pasang calon dapat dilaksanakan dengan beberapa syarat. Salah satunya adalah apabila setelah dilakukan penundaan dan sampai

5 YS Hikmania. (2018). Pergulatan Konsep Contested Election dan Uncontested Election (Studi Kasus Pemilukada Kabupaten Pati Tahun 2017). Tesis Departemen Politik dan Pemerintahan Universitas Gadjah Mada, hlm. 38.

6 C. Lay, et.al. (2017). The Rise of Uncontested Elections n Indonesia: Case Studies of Pati and Jayapura. Contemporary Southeast Asia: A Journal of International and Strategic Affairs, Volume 39, Number 3, 427-448. 
dengan berakhirnya masa perpanjangan pendaftaran hanya terdapat satu pasangan calon yang mendaftar, maka dilanjutkan ke tahapan verifikasi sampai pasangan calon tersebut dinyatakan memenuhi syarat untuk maju dalam pilkada. KPU kemudian berhak menetapkan pasangan calon terpilih pada pemilihan dengan satu paslon apabila mendapatkan suara lebih dari $50 \%$ suara sah. Jika paslon tunggal tidak bisa meraih suara sah lebih dari 50\%, akan dilakukan pemilihan ulang. Undang-Undang Nomor 10 Tahun 2016 juga mengubah aturan persyaratan bagi calon perseorangan agar dapat berkontestasi dalam pilkada, yaitu untuk calon perseorangan yang mendaftarkan diri sebagai calon gubernur dan wakil gubernur.? Kemudian, aturan ini

7 Bunyi Pasal 41 ayat (1) UU Nomor 10 Tahun 2016 adalah sebagai berikut.

a. Provinsi dengan jumlah penduduk yang termuat pada daftar pemilih tetap sampai dengan 2.000.000 (dua juta) jiwa harus didukung paling sedikit 10\% (sepuluh persen);

b. Provinsi dengan jumlah penduduk yang termuat pada daftar pemilih tetap lebih dari 2.000 .000 (dua juta) jiwa sampai dengan 6.000 .000 (enam juta) jiwa harus didukung paling sedikit 8,5\% (delapan setengah persen);

c. Provinsi dengan jumlah penduduk yang termuat pada daftar pemilih tetap lebih dari 6.000 .000 (enam juta) jiwa sampai dengan 12.000 .000 (dua belas juta) jiwa harus didukung paling sedikit 7,5\% (tujuh setengah persen);

d. Provinsi dengan jumlah penduduk yang termuat pada daftar pemilih tetap lebih dari 12.000 .000 (dua belas juta) jiwa harus didukung paling sedikit 6,5\% (enam setengah persen); dan

e. Jumlah dukungan sebagaimana dimaksud pada huruf $a$, huruf $b$, huruf $c$, dan huruf $d$ tersebar di lebih dari 50\% (lima puluh persen) jumlah kabupaten/kota di provinsi dimaksud. 
dipertegas di Pasal 41 Ayat (2). ${ }^{8}$

Aturan dalam Undang-Undang Nomor 10 Tahun 2016 bagi sebagian pasangan calon yang ingin berkompetisi lewat jalur perseorangan dirasa memberatkan, menutup peluang bagi calon perseorangan untuk ikut berkompetisi dalam pilkada. Selain itu, pada pilkada dengan calon tunggal, mayoritas diikuti oleh petahana yang memborong mayoritas dukungan partai. Di kabupaten Pati sendiri, pasangan bupati petahana Haryanto-Saiful Arifin diusung oleh delapan dari sembilan parpol di DPRD kabupaten Pati. Hal ini jelas menutup kemungkinan ada calon dari parpol lain untuk ikut serta dalam kompetisi, sedangkan calon perseorangan juga terkendala jumlah syarat dukungan. Kondisi ini hampir serupa terjadi di daerah lain yang melakukan pilkada dengan calon tunggal. Di kabupaten Buton, misalnya pasangan Umar SamiunLa Bakri yang keduanya merupakan petahana, meraih dukungan 20 kursi DPRD kabupaten Buton, dari total 25 kursi yang ada.

Studi mengenai pilkada calon tunggal melawan kotak kosong

8 Pasal 41 ayat (2) UU Nomor 10 Tahun 2016:

a. Calon perseorangan dapat mendaftarkan diri sebagai calon bupati dan calon wakil bupati serta calon walikota dan calon wakil walikota jika memenuhi syarat dukungan jumlah penduduk yang mempunyai hak pilih dan termuat dalam daftar pemilih tetap di daerah bersangkutan pada pemilihan umum atau pemilihan sebelumnya yang paling akhir di daerah bersangkutan, dengan ketentuan:

b. Kabupaten/kota dengan jumlah penduduk yang termuat pada daftar pemilih tetap sampai dengan 250.000 (dua ratus lima puluh ribu) jiwa harus didukung paling sedikit 10\% (sepuluh persen);

c. Kabupaten/kota dengan jumlah penduduk yang termuat pada daftar pemilih tetap lebih dari 250.000 (dua ratus lima puluh ribu) sampai dengan 500.000 (lima ratus ribu) jiwa harus didukung paling sedikit 8,5\% (delapan setengah persen);

d. Kabupaten/kota dengan jumlah penduduk yang termuat pada daftar pemilih tetap lebih dari 500.000 (lima ratus ribu) sampai dengan 1.000.000 (satu juta) jiwa harus didukung paling sedikit 7,5\% (tujuh setengah persen);

e. Kabupaten/kota dengan jumlah penduduk yang termuat pada daftar pemilih tetap lebih dari 1.000.000 (satu juta) jiwa harus didukung paling sedikit 6,5\% (enam setengah persen); dan

f. Jumlah dukungan sebagaimana dimaksud pada huruf a, huruf b, huruf $c$, dan huruf d tersebar di lebih dari 50\% (lima puluh persen) jumlah kecamatan di kabupaten/kota dimaksud. 
ini telah dilakukan oleh Hikmania di tahun 2018 yang menghasilkan kesimpulan bahwa keseluruhan bangunan pelaksanaan pilkada calon tunggal menerapkan dua jenis pemilu secara bersamaan, contested election dan uncontested election. Pembuat kebijakan ingin mendesain uncontested election tetapi keseluruhan regulasinya seolah-olah merupakan contested election, yaitu dengan menghadirkan kotak kosong sebagai "lawan". Akibatnya, pada level stakeholders, yaitu KPU kabupaten Pati, partai pendukung pasangan calon, partai non pendukung pasangan calon, dan Aliansi Kawal Demokrasi Pilkada Pati (AKDPP) mengalami kebingungan. Kebingungan ini dijumpai saat narasumber diminta untuk mengategorikan apakah pilkada kabupaten Pati termasuk pemilu kontestasi atau pemilu non kontestasi. Ada yang menjawab pemilu kontestasi, ada yang menyebut non kontestasi, ada pula yang mengategorikan sebagai pemilu setengah kontestasi. Argumen tulisan ini sama dengan studi tersebut, yaitu adanya ketidaksiapan infrastruktur pemilu dalam mengantisipasi efek dari mekanisme uncontested democracy. Perbedaannya, Hikmania lebih menyoroti penerapan uncontested election, namun ditopang dengan regulasi contested election. Sedangkan artikel ini fokusnya adalah belum diakomodirnya keterlibatan civil society dalam kampanye dan perselisihan hasil pemilihan pada pilkada kabupaten Pati Tahun 2017. Hal ini menyebabkan civil society yang diharapkan dapat menjadi penyeimbang di tengah dominasi calon petahana tidak memperoleh ruang dalam kontestasi pilkada Pati tahun 2017.

Studi lain adalah terkait strategi yang dilakukan oleh kelompok "kotak kosong" yang menamakan diri Aliansi Kawal Demokrasi Pilkada (AKDP) kabupaten Pati yang menyuarakan agar masyarakat Pati tidak lagi dipimpin oleh bupati petahana, Haryanto. Kehadiran

9 Y. S. Hikmania. (2018). Pergulatan Konsep Contested Election dan Uncontested Election (Studi Kasus Pilkada Kabupaten Pati Tahun 2017). Tesis. Tidak Diterbitkan. Fakultas Ilmu Sosial dan Ilmu Politik. Yogyakarta: Universitas Gadjah Mada. 
kelompok ini bertujuan sebagai pendidikan berdemokrasi, karena warga harus diberi alternatif pilihan dan merupakan bukti bahwa suara warga sangat berharga.

Temuan dalam studi ini adalah bahwa strategi yang dilakukan AKDP dalam pilkada Pati tahun 2017 adalah, pertama, melobi pihak-pihak terkait penyelenggaraan pilkada, seperti KPU, Panwas, dan Kepolisian bahwa mereka berhak untuk menyelenggarakan kegiatan sosialisasi dan kampanye pilihan kotak kosong. Kedua, dengan membuka akses kepada pembuat kebijakan dan memobilisasi sumber daya yang mereka miliki. Membuka akses ini dilakukan dengan cara membuat mereka dikenal oleh media massa sehingga menjadi media darling. Dengan menjadi media darling, mereka memiliki daya tawar yang lebih di mata para pembuat kebijakan. Sedangkan upaya untuk memobilisasi sumber daya dilakukan AKDP dengan mengadakan deklarasi yang mengundang warga kabupaten Pati yang medukung gerakan mereka. Ketiga, AKDP berusaha menggalang pilihan dan mobilisasi suara pemilih agar memilih kotak kosong dengan menggunakan media Facebook Group, yaitu grup relawan kotak kosong Pati, dan relawan kotak kosong Pati Bumi Mina. Keempat, mengontrol informasi kepada pemilih dengan jalan membentuk opini publik melalui kerangka (frame). Hal ini dilakukan karena AKDP memiliki kekurangan dalam hal sumber daya yang terbatas. Mereka tidak mendapat alokasi dana kampanye dari negara sehingga harus menggunakan dana sendiri yang digalang secara sukarela. Kelima, melakukan advokasi dengan cara memperluas jumlah pendukung melalui media sosial, utamanya menyasar segmen pemilih muda serta pemasangan spanduk yang kemudian menimbulkan reaksi dari tim sukses bupati petahana, yaitu dengan dicopotnya spanduk AKDP. Pencopotan spanduk ini menjadi berita di media massa lokal, yang berimbas pada meningkatnya simpati 
dan dukungan. ${ }^{10}$

Persamaan dari kedua studi ini adalah membahas keterlibatan civil society dalam bentuk kelompok kepentingan serta civil society secara keseluruhan dalam melawan hegemoni dari petahana. Perbedaannya, pada titik fokusnya dimana Ikhsan Darmawan menitikberatkan pada strategi yang dilakukan oleh AKPD dalam pilkada calon tunggal di kabupaten Pati. Sedangkan tulisan ini lebih menyoroti infrastruktur regulasi yang dibangun tidak memberikan ruang yang sama bagi perwujudan civil society—GERAM Pati-untuk menggalang dukungan bagi kotak kosong melalui kampanye dan penyelesaian sengketa hasil pilkada calon tunggal.

Munculnya calon tunggal dalam pilkada di Indonesia ini sesungguhnya merupakan sebuah perwujudan demokrasi yang sama sekali tidak terbayangkan dalam konsep demokrasi ideal menurut Dahl. Hal ini menunjukkan bahwa perkembangan demokrasi di suatu negara sangat dipengaruhi oleh kondisi masyarakat setempat serta peta kekuatan politiknya. Gugatan yang dilakukan oleh kelompok pendukung kotak kosong menunjukkan bahwa tata kelola pemilihan masih dimaknai sebatas pada penyelesaian administrasi pemilihan. Mekanisme kontestasi yang disiapkan tidak diimbangi dengan pelembagaan birokrasi penyelenggara pemilu dan badan peradilannya. Luis Eduardo Medina Torres dan Edwin Cuitláhuac Ramirez Diaz kemudian memberikan penekanan pada sebuah mekanisme yang disebut dengan electoral governance yang merupakan sebuah rangkaian proses yang dimulai dengan berlakunya Undang-Undang, diberlakukannya sebuah sistem administratif serta proses yudisial, dan berakhir pada proses tersebut kemudian kembali lagi ke awal."

10 Ikhsan Darmawan. (2017). Peran dan Strategi Kelompok "Kotak Kosong” Dalam Pilkada Calon Tunggal Kabupaten Pati Tahun 2017: Studi Pendahuluan. Jurnal Wacana Politik, Vol. 2, No. 1, 45-51.

11 L. E. Torres \& E. C. Diaz. (2015). Electoral Governance: More Than Just Electoral Administration. Mexican Review Law, Volume VIII, New Series Number 1, p. 33-46. 


\section{Civil Society: Konsep dan Peranan dalam Demokrasi}

Konsepsi modern tentang civil society pertama kali digunakan oleh Hegel dalam Philosophy of Right pada tahun 1821. Hegel menyebutkan bahwa "civil society is sphere of ethical life interposed between the family and the state". Definisi kemudian dikembangkan pada tahun 1994 oleh Larry Diamond yang menyebutkan bahwa "civil society is the realm of organized social life that is voluntary, self-generating, self-supporting, autonomous from the state, and bound by legal order or set of shared rules". ${ }^{2}$ Berdasarkan pandangan dari tokoh-tokoh liberal ini, maka dapat disimpulkan bahwa civil society memiliki tujuan membentuk sebuah masyarakat yang mempunyai kemandirian dan terbebas dari hegemoni negara.

Dalam bahasa Indonesia, istilah civil society ${ }^{13}$ sulit diterjemahkan secara langsung sebagai masyarakat sipil. Hal ini disebabkan karena di Indonesia, istilah sipil diterjemahkan sebagai bukan militer (non militer). Civil society dapat didefinisikan sebagai wilayah-wilayah kehidupan sosial yang terorganisasi dan bercirikan antara lain: kesukarelaan (voluntary), keswasembadaan (self-generating), dan keswadayaan (self-supporting), kemandirian tinggi berhadapan dengan negara, dan keterikatan dengan norma-norma atau nilai-nilai hukum yang diikuti oleh warganya. ${ }^{14}$ Pandangan ini pada dasarnya menganggap civil society sebagai sebuah gerakan rakyat untuk membebaskan diri dari hegemoni negara. Civil society dalam konteks ini mengandung elemen adanya sebuah masyarakat yang beradab (civilized society),

12 S. S. Hadiwijoyo. (2012). Negara, Demokrasi dan Civil Society. Yogyakarta: Graha Ilmu, p. 73.

13 Istilah civil society pertama kali digunakan di Eropa pada abad 18, sebagai terjemahan dari bahasa Romawi societas civilis yang untuk beberapa bahasa pada waktu itu diartikan sebagai state dan political society atau seluruh kenyataan yang menyangkut politik. Locke menerjemahkan civil society sebagai civil government, Kant menerjemahkannya sebagai burgerliche gesselchaft, dan Rousseau menyebutnya sebagai e'tat civil. Hikam, Muhammad AS. (1996). Demokrasi dan Civil Society, p. 2. Jakarta: LP3S.

14 Muhammad A. S. Hikam. (1996). Demokrasi dan Civil Society, p.3. Jakarta: LP3S. 
yaitu sebuah masyarakat yang menganut aturan-aturan yang berkaitan dengan sistem hukum yang berlaku, daripada menggantungkan pada aturan yang bersifat otoriter.

Civil society juga kerap disebut sebagai masyarakat madani, (pertama kali dicetuskan oleh Nurcholis Madjid dan beberapa tokoh ICMI) yang berarti masyarakat yang beradab, berakhlak mutlak, dan berbudi pekerti luhur. Madani diambil dari nama kota Madinah yang diungkapkan dengan istilah madaniyah, tamadun, dan hadlarah yang berarti peradaban. ${ }^{15}$ Sedangkan Neera Chandoke mendefinisikan civil society sebagai suatu tempat dimana masyarakat masuk ke dalam hubungan dengan negara (the site at which society enters into a relationship with the state). Civil society juga menjadi dasar atau tempat berpijak bagi munculnya wacana rasional yang memiliki potensi untuk mempertanyakan pertanggung-jawaban negara. Sehubungan dengan hal tersebut, terdapat empat persyaratan yang harus dipenuhi bagi keberadaan civil society, yaitu (1) nilai dari civil society yang berupa partisipasi politik dan state accountability; (2) institusi dari civil society berupa forum yang representatif dan asosiasi sosial; (3) perlindungan dari civil society yang berhubungan dengan hak-hak individual secara umum; (4) anggota civil society adalah semua individu yang dilindungi secara hukum. ${ }^{16}$ Dari pemaparan konsep-konsep tersebut, maka istilah civil society-lah yang digunakan dalam tulisan ini. Untuk mempermudah memperoleh gambaran, civil society termanifestasikan dalam berbagai organisasi yang dibuat oleh masyarakat di luar pengaruh negara. Bentuknya bisa berupa Lembaga Swadaya Masyarakat (LSM), organisasi sosial dan keagamaan, paguyuban, serta kelompokkelompok kepentingan (interest group).

Kemudian, terkait perananannya di negara demokrasi, civil society sendiri memiliki beberapa kontribusi, yaitu (1) menyediakan wahana

15 S. S. Hadiwijoyo. (2012). Negara, Demokrasi dan Civil Society, p. 75. Yogyakarta: Graha Ilmu. 16 S. S. Hadiwijoyo. (2012). Negara, Demokrasi dan Civil Society, p. 77. Yogyakarta: Graha Ilmu. 
sumber daya politik, ekonomi, kebudayaan, dan moral untuk menjaga dan mengawasi negara; (2) mendorong persaingan yang demokratis di tengah-tengah masyarakat yang plural; (3) meningkatkan efektivitas politik dan kesadaran kewarganegaraan (citizenship); (4) menjaga stabilitas negara dan mencegah munculnya rezim otoriter; dan (5) sebagai wadah seleksi dan lahirnya para pemimpin politik yang baru. ${ }^{17}$

Kemunculan GERAM Pati sebagai sebuah kekuatan civil society hadir dengan membawa fungsi substitusi, yaitu melakukan serangkaian aktivitas yang belum atau tidak dilakukan negara dalam rangka melayani kepentingan masyarakat luas. Dominasi petahana dalam kontestasi di kabupaten Pati telah menutup ruang bagi lahirnya alternatif calon pemimpin baru sehingga dorongan untuk melakukan perubahan tersebut diwujudkan dengan lahirnya GERAM Pati. Selain itu, civil society juga memiliki fungsi penyeimbang, yaitu dengan melakukan advokasi, pendampingan bahkan praktik-praktik oposisi untuk mengimbangi kekuatan hegemoni negara. Kuatnya petahana di kabupaten Pati, mendorong munculnya kekuatan penyeimbang melalui civil society yang melakukan serangkaian upaya sebagai oposisi guna mengimbangi hegemoni, dalam hal ini calon petahana.

\section{Peta Sosial dan Dinamika Politik di Pati}

Pati merupakan sebuah kota di Jawa Tengah yang berada di jalur Pantura Semarang-Surabaya. Jalur ini merupakan jalur ramai yang kerap digunakan sebagai jalur transit. Pati berbatasan langsung dengan Laut Jawa (Utara), Rembang (Timur), Blora dan Grobogan (Selatan), Kudus dan Jepara (Barat). Dengan luas wilayah $1.489 \mathrm{~km}^{2}$, Pati memiliki 21 kecamatan dan 406 desa. Jumlah penduduk Pati berkisar 1.206.000 jiwa dengan jumlah pemilih tetap sebanyak 1.030.676 pemilih.

17 A. Budiman. (2018). Kontribusi Masyarakat Sipil di Tahun Politik. Disampaikan dalam Kuliah Umum S2 Tata Kelola Pemilu di Universitas Gadjah Mada. Yogyakarta: Komisi Pemilihan Umum. 
Berbeda dengan pilkada tahun 2017 yang hanya diikuti oleh calon tunggal, pilkada tahun 2011 di Pati lebih kompetitif. Pilkada 2011 diikuti oleh enam pasangan calon, terdiri dari tiga pasangan calon yang diusung oleh partai dan tiga pasangan calon independen. Saat itu, PDIP merupakan partai dominan di Pati. Namun, kondisi tersebut berubah sejak PDIP pecah dikarenakan masalah internal partai yang hingga mengakibatkan munculnya Pemungutan Suara Ulang (PSU) pilkada 2012. Pada saat PSU pilkada 2012, Pasangan bupati H. Haryanto dan wakil bupati Pati H. M. Budiyono (partai pengusung PKB, PPP, PKS, Gerindra, Hanura, PPI, dan PKPB) memenangkan pilkada Pati mengalahkan pasangan H. Imam Suroso, MM. dan Sujoko, S. Pd. (PDIP). Pada Pemilu 2014, Gerindra menjadi partai penyumbang terbanyak dalam komposisi DPRD kabupaten Pati 2014-2019 dengan masing-masing delapan anggotanya duduk dalam parlemen daerah kabupaten Pati. Kini, selisih perolehan kursi partai di Pati cenderung merata dikarenakan tidak adanya partai dominan. Akibatnya, tidak ada calon yang dominan selain petahana untuk ikut berkompetisi dalam pilkada Pati tahun 2017.

Menjelang pilkada 2017, isu pecahnya kongsi antara HaryantoBudiyono mulai santer terdengar. Puncaknya, tanggal 5 Februari 2016 Haryanto-Arifin melakukan pendaftaran di kantor DPC PDIP Pati, padahal diketahui sebelumnya Budiyono juga telah mendaftarkan diri ke kantor DPC PDIP Pati. Dalam usahanya untuk maju ke pilkada Pati 2017, Budiyono yakin menggunakan kendaraan politik PKB. Menurutnya, dia telah mendapat dukungan dari PKB karena pada saat itu, dia adalah Ketua Dewan Syuro PKB Pati. Budiyono dengan kendaraan PKB (6 kursi) memiliki peluang untuk melobi PPP (3 kursi), PKS (5 kursi), dan terakhir adalah Nasdem (4 kursi). Jika dicermati, pola koalisi partai politik di Pati untuk PKB, PKS, dan PPP sejak pilkada 2006, memang PPP berkoalisi dengan PKS dan pada pilkada 2011/PSU 2012 PPP berkoalisi dengan PKS dan PKB. UU No. 10 Tahun 
2016, Pasal 40 Ayat (1) memberikan syarat Parpol/Gabungan Parpol dapat mendaftarkan pasangan calon jika telah memenuhi persyaratan perolehan paling sedikit 20\% dari jumlah kursi Dewan Perwakilan Rakyat Daerah (DPRD). Dalam hal ini, skema penghitungannya, Budiyono dapat maju dikarenakan memiliki dukungan lebih dari $20 \%$ dari jumlah kursi di DPRD Pati. Namun, karena terdapat sifat pragmatis dalam sebuah koalisi yang mengesampingkan platform dan ideologi, ditambah dengan sistem sentralistik terpusat dari setiap parpol dalam menentukan kandidatnya, akhirnya semua parpol kecuali Nasdem $^{18}$ memilih Haryanto-Arifin sebagai calon tunggal untuk maju ke pilkada Pati 2017. Di luar dugaan, PKB lebih condong memberikan dukungannya (6 kursi) ke Pasangan Haryanto-Arifin. Budiyono akhirnya tidak bisa maju dalam pilkada 2017.

Jika dilihat dari segi ketokohan organisasi, seperti Nahdlatul Ulama (NU) dan Muhamadiyah di Pati, kedua ormas ini memilih untuk mendukung petahana dikarenakan tidak memiliki calon alternatif yang akan diusung dalam pilkada Pati tahun 2017. Adanya klaim dari NU dan Muhammadiyah mendorong munculnya dukungan terhadap calon tunggal. Klaim NU menyatakan bahwa memilih kotak kosong merupakan perbuatan yang zalim dan sesat. ${ }^{19}$ Sedangkan Muhammadiyah mengarahkan warga untuk tidak boleh golput, karena secara nashab calon bupati dan wakil bupati masih memiliki darah Muhammadiyah. ${ }^{20}$

18 Saat ini Budiyono menjadi Ketua Nasdem di tingkat DPD Kabupaten Pati.

19 Tempo.co, NU Jawa Tengah Terbitkan Fatwa Calon Tunggal di Pilkada, Senin, 13 Februari 2017 11:32 WIB, diakses tanggal 1 Juni 2018 pukul 17:00 WIB.

20 Krjogja.com, Pilkada Pati, Muhammadiyah Imbau Warga Tak 'Golput', Selasa, 24 Januari 2017 21:44 WIB, diakses tanggal 1 Juni 2018 pukul 17:10 WIB. 


\section{Pilkada Pati 2017: Kemunculan Pasangan Calon Tunggal}

Pelaksanaan tahapan pemilihan bupati dan wakil bupati Pati tahun 2017 sudah berjalan sesuai peraturan perundangan-undangan. Pada tanggal 22 September 2016, gabungan dari delapan partai politik mendaftarkan Haryanto sebagai bakal calon bupati dan Saiful Arifin sebagai bakal calon wakil bupati ke KPU kabupaten Pati. Haryanto sendiri merupakan petahana bupati pemenang pilkada 2012. Dengan background kental seorang birokrat, Haryanto menduduki struktur tinggi dalam organisasi NU Pati. Dalam pilkada 2017, Haryanto menggandeng Saiful Arifin yang merupakan seorang pengusaha sukses di bidang telekomunikasi, perhotelan, perikanan, pertanian, hingga peternakan, yang juga merupakan ketua HIPMI Jakarta Selatan, komite bidang BUMN, ketua DPP KBM Kemaritiman, ketua bidang Usaha Ikatan Keluarga Kabupaten Pati, dan juga merupakan manajer Safin FC dan Persipa Pati. Pasangan ini diusung oleh delapan partai politik, yaitu: 
Jumlah Partai Politik Pengusung Pasangan Calon Bupati dan Wakil Bupati Haryanto - Saiful Arifin

\begin{tabular}{|l|l|l|c|}
\hline \multicolumn{1}{|c|}{ Nama Calon } & \multicolumn{1}{c|}{$\begin{array}{c}\text { Tanggal } \\
\text { Pendaftaran }\end{array}$} & \multicolumn{1}{|c|}{ Partai Pengusung } & $\begin{array}{c}\text { Jumlah } \\
\text { Kursi }\end{array}$ \\
\hline \multirow{2}{*}{$\begin{array}{l}\text { H. HARYANTO, } \\
\text { SH., MM., M.Si. } \\
\text { dan H. SAIFUL } \\
\text { ARIFIN }\end{array}$} & 22 September & PDI Perjuangan & 8 \\
\cline { 3 - 4 } & & Partai Gerindra & 8 \\
\cline { 3 - 4 } & Partai Keadilan Sejahtera & 5 \\
\cline { 3 - 4 } & Partai Demokrat & 6 \\
\cline { 3 - 4 } & Partai Golongan Karya & 6 \\
\cline { 3 - 4 } & Partai Hati Nurani Rakyat & 4 \\
\cline { 3 - 4 } & $\begin{array}{l}\text { Partai Persatuan } \\
\text { Pembangunan }\end{array}$ & 3 \\
\cline { 3 - 4 } & & $\begin{array}{l}\text { Partai Kebangkitan } \\
\text { Bangsa }\end{array}$ & 6 \\
\hline \multirow{2}{*}{ Jumlah Kursi } & & 46 & 6 \\
\hline
\end{tabular}

Jika berpedoman pada ketentuan yang ada, partai politik atau gabungan partai politik sebenarnya sudah dapat mendaftarkan/ mengusung bakal pasangan calon bupati dan wakil bupati dengan 20\% dukungan dari jumlah kursi DPRD hasil Pemilu Tahun 2014. Untuk kabupaten Pati yang memiliki total 50 kursi, berarti sudah cukup dengan memperoleh setidaknya 10 kursi. ${ }^{21}$ Namun yang terjadi, delapan dari sembilan partai di DPRD Pati berbondong-bondong mendukung pasangan calon Haryanto-Saiful Arifin. Hanya Partai Nasional Demokrat (Nasdem) yang belum mendukung siapa pun.

21 Berdasarkan Keputusan KPU Kabupaten Pati Nomor 17/Kpts-PILBUP/KPUkab-012.329311/2016 tentang Pedoman Teknis Pencalonan Pemilihan Bupati dan Wakil Bupati Pati Tahun 2017. 
Namun, sampai batas waktu penutupan pendaftaran bakal pasangan calon ternyata hanya satu bakal pasangan calon yang didaftarkan oleh partai politik/gabungan partai politik. Mengingat hanya terdapat satu pasangan calon yang mendaftar, KPU kabupaten Pati kemudian: (1) menetapkan penundaan tahapan pemilihan pada tanggal 24 September 2016; (2) melakukan sosialisasi pemilihan selama tiga hari, yaitu tanggal 26-28 September 2016; dan (3) memperpanjang pendaftaran paling lama tiga hari, yaitu tanggal 29 September-1 Oktober 2016.

Perpanjangan pendaftaran ini secara nalar merupakan hal yang percuma, mengingat tidak mungkin akan ada pasangan calon lain yang dapat diusung oleh partai politik. Partai politik yang tersisa hanyalah Nasdem dengan perolehan empat kursi di DPRD Pati, sehingga tidak memenuhi syarat untuk mengusung pasangan calon sendiri. Secara regulasi pun, sudah tidak dimungkinkan adanya calon perseorangan yang mendaftar dalam masa perpanjangan pendaftaran. Hal ini dikarenakan untuk calon perseorangan, masa perpanjangan dapat digunakan apabila pasangan calon perseorangan tersebut telah menyerahkan syarat dukungan serta telah mengikuti penelitian administrasi dan faktual, walaupun tidak mendaftar pada masa pendaftaran awal (tanggal 21 s.d 24 September 2016) mereka dapat mendaftar pada masa perpanjangan pendaftaran.

Untuk mengantisipasi hal tersebut, kemudian muncul Surat Edaran KPU Nomor 533/KPU/IX/2016 tentang Perpanjangan Masa Pendaftaran Pasangan Calon yang pada pokoknya memberikan kesempatan bagi parpol atau gabungan parpol untuk mengubah komposisi parpol pendukung guna memberikan kesempatan bagi parpol yang belum ikut mengusung pasangan calon karena perolehan kursinya tidak mencapai sekurang-kurangnya 20\%. Dengan adanya kemunculan Surat Edaran tersebut, lalu: (1) KPU kabupaten Pati kemudian menetapkan perubahan penundaan tahapan pemilihan, yaitu tanggal 28 September 2016; (2) melakukan sosialisasi Pemilihan 
selama tiga hari, yaitu tanggal 29 September sampai dengan 1 Oktober 2016, dan; (3) memperpanjang pendaftaran paling lama tiga hari, yaitu tanggal 2-4 Oktober 2016. Kemudian, sampai dengan berakhirnya masa perpanjangan pendaftaran, tidak ada perubahan pada komposisi dukungan partai politik dan tidak ada lagi pasangan calon baru yang diusung. Oleh karena itu, pada tanggal 24 Oktober 2016, KPU kabupaten Pati menetapkan pasangan calon Haryanto dan Saiful Arifin sebagai calon tunggal.

\section{Kemunculan Gerakan Masyarakat Pati (GERAM Pati)}

Penetapan pasangan Haryanto-Saiful Arifin sebagai calon tunggal memunculkan sebuah gerakan politik mendukung kotak kosong yang tak disangka sebelumnya. Proses pemilihan yang sebenarnya tidak memiliki lawan ternyata menghadapi perlawanan yang cukup berarti dari para pendukung/relawan kotak kosong. Hal ini bermula dengan kemunculan sebuah gerakan politik yang mengatasnamakan dirinya Gerakan Masyarakat Pati atau yang lebih dikenal dengan sebutan GERAM Pati. Gerakan ini terdiri dari sekumpulan Lembaga Swadaya Masyarakat (LSM) yang bergabung dengan alasan dan tujuan yang sama, mereka di antaranya Aliansi Kawal Demokrasi Pilkada Pati (AKDPP), Forum Komunikasi LSM Penegak Demokrasi, Aliansi Kotak Kosong, dan anggota masyarakat/civil society lainnya yang tidak menyetujui adanya pasangan calon tunggal petahana.

GERAM Pati muncul dan aktif berkembang pada mulanya di media sosial. Gerakan ini merupakan bentuk perlawanan secara politik ketika delapan dari sembilan partai di Pati hanya mencalonkan satu pasangan calon. Gerakan ini juga mengandung unsur kekecewaan terhadap partai politik yang dianggap gagal memberikan pendidikan politik terhadap kader partai, yang mengakibatkan partai tidak memiliki kader yang mumpuni untuk diusung dalam pilkada. Mereka 
juga mengusung rasa tidak suka/kekecewaan terhadap calon yang ada, karena petahana dianggap selama ini tidak pro rakyat kecil.

GERAM Pati dimotori oleh Budiyono selaku wakil bupati Pati yang memang dalam beberapa tahun terakhir sudah tidak sepaham lagi dengan Haryanto selaku bupati Pati. Budiyono adalah salah satu orang yang tidak bisa maju dalam pilkada 2017. Selain itu, ada beberapa anggota DPRD kabupaten Pati dari partai Nasdem, misalnya Hj. Muntamah, yang juga turut membesarkan gerakan kotak kosong. Beberapa tokoh yang sejak awal mendeklarasikan diri sebagai bakal calon yang pada akhirnya tidak jadi mencalonkan diri karena terhalang partai pengusung, disinyalir juga berada di belakang relawan kotak kosong, atau setidak-tidaknya sebatas simpatisan. GERAM Pati juga didukung oleh masyarakat yang selama ini menolak pendirian pabrik semen di Sukolilo, Kayen, dan Tambakromo, serta beberapa Lembaga Swadaya Masyarakat (LSM), dan disinyalir juga didukung oleh PNSPNS yang kecewa dikarenakan kuatnya klientelisme Bupati dalam pengisian jabatan-jabatan strategis selama masa pemerintahannya. ${ }^{22}$

\section{Dinamika GERAM Pati dalam Pilkada Pati 2017: Strategi dan Taktik}

Dalam upayanya untuk berkompetisi dengan Bupati petahana, beragam upaya telah dilakukan oleh GERAM Pati di antaranya dengan melakukan sosialisasi dan sekaligus mengampanyekan kotak kosong. Selain memasang baliho-baliho ajakan memilih kotak kosong, mereka juga sempat melakukan sejumlah demo dan membagikan selebaranselebaran berisi 12 kritik terhadap pasangan calon Haryanto-Saiful Arifin yang digunakan sebagai alasan kenapa harus memilih kotak kosong, yaitu: (1) bupati dianggap tidak pro lingkungan karena tetap menyetujui pendirian pabrik semen sehingga GERAM Pati

22 Wawancara dengan salah satu Pegiat Kotak Kosong, dilakukan pada tanggal 1 April 2018, di desa Muktiharjo, Kecamatan Margorejo, kabupaten Pati. 
berpendapat bahwa Bupati telah menggugat rakyatnya sendiri; (2) pro investor tidak pro rakyat. Investor dibela habis-habisan, dan rakyat sendiri diacuhkan. Aturan bisa dimudahkan jika investor yang meminta, seperti menganggap investor adalah raja; (3) tidak ada ahli tata kota. Banyak mendirikan bangunan, tetapi tata letaknya tidak sesuai dan semua diganti wayang. Landmark tani pun diganti dengan wayang. Banyak membangun pasar unggulan dengan dana milyaran namun tidak bermanfaat karena pengunjung, makin hari makin sepi dan merugi; (4) tidak pro pedagang kecil. Minimarket menjamur, ijin usaha toko modern diabaikan, sehingga pedagang kecil merugi; (5) tidak pro pariwisata. Pati merupakan daerah kaya tempat wisata tapi potensi ini tidak dimanfaatkan dengan maksimal. Pada lima tahun pertama pemerintahan bupati Haryanto, tidak terdapat kemajuan yang signifikan dalam mengembangkan pariwisata; (6) tidak pro Persipa (Persatuan Sepak Bola Pati). Klub sepak bola kebanggaan masyarakat Pati ini tidak diperhatikan, tidak diberi anggaran sehingga Persipa harus mencari dana sendiri untuk menggaji pemain; (7) tak bisa menjadi pemimpin yang patut diteladani. Salah satu penyebabnya adalah biaya pengurusan sertifikat tanah mahal yang bahkan biaya tersebut bisa digunakan untuk membeli tanah; (8) bupati dinilai tidak tegas menangani karaoke. Tempat karaoke menjamur dan tak mampu menutup tempat karaoke, justru didemo balik oleh pemandu karaoke; (9) kontrol terhadap perusahaan yang mengganggu masyarakat, dianggap lemah. Bupati dinilai tidak mampu mengatasi pabrik ikan yang baunya menyengat; (10) tak ada kebaruan dan inovasi. Hal ini disebabkan karena visi misi ke depan sama; (11) perubahan minim, karena hanya melanjutkan program-program yang telah dijalankan; (12) GERAM Pati kemudian menyatakan bahwa bupati Haryanto dipilih delapan partai, untuk melawan rakyat. Dan, mendeklarasikan untuk memilih kotak kosong daripada diktator dalam dukungan 
partai. $^{23}$

Kemudian, diketahui bahwa Budiyono (wakil bupati pasangan Haryanto periode sebelumnya) memberikan disposisi kepada Kepala Disbupparpora untuk melakukan sosialisasi kotak kosong, dan memfasilitasi relawan kotak kosong dalam bentuk penggunaan mobil dinas wakil bupati. Relawan kotak kosong juga sering melakukan aksi tanpa ijin, seperti mengadakan pagelaran ketoprak, jalan santai, dan longmarch. Mereka juga mengadukan ketua dan anggota panitia Pengawas Pemilihan Umum (Panwaslu) kabupaten Pati ke Dewan Kehormatan Penyelenggara Pemilihan Umum (DKPP) terkait dugaan pelanggaran kode etik. Relawan kotak kosong ini juga melakukan upaya penekanan terhadap Panwaslu kabupaten Pati dan Gakkumdu dalam memproses dugaan temuan 14 laporan money politic. ${ }^{24}$

Namun sayangnya, segala upaya kampanye yang dilakukan oleh GERAM Pati untuk memenangkan kotak kosong ini mengalami kegagalan. Berdasarkan hasil penghitungan suara yang dilakukan oleh Komisi Pemilihan Umum kabupaten Pati pada tanggal 23 Februari 2017, pasangan calon tunggal Haryanto-Saiful Arifin menang telak dengan perolehan suara sebanyak 519.675 suara, sedangkan kolom kosong sebanyak 177.762 suara. ${ }^{25}$ Selisih suara antara pasangan calon dan kolom kosong adalah 49,02\% dari total suara sah sejumlah 697.437 suara.

Merasa tidak terima, pada tanggal 28 Februari 2017 tim advokasi Gerakan Masyarakat Pati (GERAM Pati) melayangkan surat

23 Asep Mufti Abhan dan Achwan. (2017). Pasangan Calon Melawan Kolom Kosong: Potret Pemilihan. bupati dan wakil bupati Pati Tahun 2017, p. 49. Semarang: Rafi Sarana Perkasa.

24 Ibid., p. 50-57.

25 Berdasarkan Rekapitulasi Hasil Penghitungan Suara Pemilihan Umum Bupati dan Wakil Bupati Pati Tahun 2017 tingkat kabupaten oleh Komisi Pemilihan Umum Kabupaten Pati dan Keputusan KPU Kabupaten Pati Nomor 16/Kpts/KPU-Kab-012.329311/2017 tanggal 23 Februari 2017 tentang Penetapan Rekapitulasi Hasil Penghitungan Perolehan Suara dan Hasil Pemilihan Bupati dan Wakil Bupati Pati Tahun 2017. 
Permohonan Pembatalan Keputusan KPU kabupaten Pati Nomor: 16/ Kpts/KPU-Kab.012.329311/2017 tentang Penetapan Rekapitulasi Hasil Pemilihan Bupati dan Wakil Bupati Tahun 2017. ${ }^{26}$ Sutiyo atas nama Ketua Aliansi Kawal Demokrasi Pilkada Pati (AKDPP) dan para pengurus sekaligus aktivis GERAM Pati lainnya tetap mengajukan permohonan sengketa ke Mahkamah Konstitusi. Menurut Pemohon (GERAM Pati), selisih perolehan 49,02\% tersebut disebabkan oleh adanya kecurangan yang dilakukan secara terstruktur, sistematis. dan masif.

\section{Putusan Mahkamah Konstitusi: Sebuah Cermin Uncontested Democracy}

Menurut Mahkamah Konstitusi, pemohon (GERAM Pati) tidak memiliki kedudukan hukum (legal standing) untuk mengajukan permohonan perselisihan penetapan perolehan suara tahap akhir hasil pemilihan calon bupati dan calon wakil bupati Pati Tahun 2017. ${ }^{27}$ GERAM Pati sebagai pemohon bukan pasangan calon bupati dan calon wakil bupati, bukan pula pemantau yang terdaftar karena hingga ditutupnya masa pendaftaran pemantau, tidak ada lembaga pemantau dalam negeri yang mendaftar.

Kemudian, berdasarkan ketentuan Pasal 158 Ayat (2) UndangUndang Nomor 10/2016 juncto Pasal 8 Ayat (2) PMK Nomor 2/2017, pemohon dapat mengajukan permohonan pembatalan keputusan penetapan perolehan suara tahap akhir hasil pemilihan calon bupati

26 Geram Pati mengajukan permohonan pada tanggal 28 Februari 2017 dan diregister oleh MK dengan nomor perkara 41/PHP.BUP-XV/2017.

27 Berdasarkan ketentuan Peraturan MK Nomor 2 Tahun 2016, tentang pedoman beracara dalam perkara perselisihan hasil pemilihan Gubernur, Bupati, dan Walikota dengan 1 pasangan calon, pihak yang dapat mengajukan permohonan di Mahkamah Konstitusi atas perselisihan hasil pemilihan Calon Bupati dan Wakil Bupati Pati Tahun 2017 adalah: (a) Pasangan Calon Bupati dan Calon Wakil Bupati Pati; (b) Pemantau Pemilihan Dalam Negeri yang terdaftar dan Memperoleh Akreditasi dari KPU Kabupaten Pati. 
dan wakil bupati apabila memenuhi ketentuan selisih suara, sebagai berikut:

Ketentuan Selisih Suara Permohonan Pembatalan Keputusan Penetapan Perolehan Suara Tahap Akhir Hasil Pemilihan Calon Bupati dan Wakil Bupati

\begin{tabular}{|l|l|c|}
\hline No. & Jumlah Penduduk & $\begin{array}{c}\text { Prosentase Selisih Suara Paling Banyak dari } \\
\text { Total Suara Sah Hasil Pemilihan }\end{array}$ \\
\hline 1. & $\leq 250.000$ & $2 \%$ \\
\hline 2. & $>250.000-500.000$ & $1,5 \%$ \\
\hline 3. & $>500.000-1.000 .000$ & $1 \%$ \\
\hline 4. & $>1.000 .000$ & $0,5 \%$ \\
\hline
\end{tabular}

Kabupaten Pati sendiri memiliki jumlah penduduk lebih dari 1.000.000 jiwa, tepatnya sebanyak 1.279.950 jiwa. ${ }^{28}$ Dengan demikian, permohonan pemohon tidak memenuhi syarat selisih perolehan suara untuk bisa mengajukan permohonan, yaitu selisih suara maksimal $0,5 \%$ dari total suara sah. Seperti yang diketahui, selisih pasangan calon dan kolom kosong mencapai 49,02\%, yaitu sebanyak 341.913 suara.

Selain itu, permohonan perselisihan penetapan perolehan suara tahap akhir hasil pemilihan calon bupati dan wakil bupati Pati tahun 2017 dianggap telah kadaluwarsa, yakni melewati batas maksimal yang ditentukan oleh Peraturan Perundang-undangan. Permohonan dapat dimohonkan kepada Mahkamah Konstitusi dalam jangka waktu paling lambat tiga hari kerja terhitung sejak termohon (KPU kabupaten Pati) mengumumkan perolehan suara hasil pemilihan. ${ }^{29}$

28 Berdasarkan Data Agregat Kependudukan Kabupaten Pati Tahun 2017 yang dikeluarkan oleh Dinas Kependudukan dan Pencatatan Sipil (Disdukcapil) Kabupaten Pati tanggal 15 Maret 2017.

29 Penetapan Rekapitulasi Hasil Penghitungan Perolehan Suara dan Hasil Pemilihan Bupati dan Wakil Bupati Pati Tahun 2017 ditetapkan oleh Termohon tanggal 23 Februari 2017 pukul 15:05 WIB, sedangkan Pemohon mendaftarkan Permohonan di Kepaniteraan Mahkamah Konstitusi pada tanggal 28 Februari 2017 pukul 21:12 WIB. 
Identitas pemohon pun dianggap tidak jelas, tidak konsisten, dan tidak benar sesuai kaidah hukum yang berlaku. Pada identitasnya, pemohon menyebutkan sebagai kelompok GERAM Pati. Pada permohonannya, pemohon menyebutkan sebagai aliansi dari sejumlah organisasi masyarakat sipil Pati, seperti Aliansi Kawal Demokrasi Pilkada Pati (AKDPP), Forum Komunikasi LSM Penegak Demokrasi, dan sejumlah individu serta simpatisan aliansi kotak kosong. Pemohon juga menyebutkan bahwa pemohon adalah para aktivis pro demokrasi yang tergabung dalam GERAM Pati alias aliansi kotak kosong untuk Pati yang bermartabat.

Penyebutan identitas dan alamat termohon tidak benar, di kabupaten Pati tidak ada Komisi Independen Pemilihan dan alamat termohon tidak sesuai dengan alamat pada kop resmi kantor Komisi Pemilihan Umum kabupaten Pati. Pemohon pun dalam permohonan salah alamat, sesuai dengan Undang-Undang Nomor 10 Tahun 2016 dinyatakan, perselisihan hasil pemilihan adalah perselisihan antara KPU Prov./KPU Kab., dan peserta pemilihan mengenai penetapan perolehan suara hasil pemilihan. Pemohon juga tidak mampu menjelaskan pelanggaran yang dianggap terstruktur, sistematis, dan masif dilakukan di mana, oleh siapa, kapan, dan dengan cara bagaimana. Terakhir, bahwa terkait pelanggaran pilkada selain perselisihan suara adalah ranah Panwas, GAKKUMDU, Peradilan Pidana, PTUN/DKPP, bukan MK.

Pasangan calon Haryanto-Saiful Arifin sebagai pihak terkait, mengajukan permohonan untuk mengabulkan eksepsi untuk seluruhnya, menolak permohonan pemohon untuk seluruhnya, dan menyatakan benar dan tetap berlaku Keputusan Komisi Pemilihan Umum kabupaten Pati Nomor 16/Kpts/KPU-Kab.012.329311/2017 tentang Penetapan Rekapitulasi Hasil Penghitungan Perolehan Suara dan Hasil Pemilihan Bupati dan Wakil Bupati Pati Tahun 2017 tanggal 23 Februari 2017. Hasil dari putusan MK yaitu mengabulkan eksepsi 
KPU kabupaten Pati dan eksepsi pasangan calon Haryanto-Saiful Arifin terkait gugatan GERAM Pati yang melewati tenggang waktu pengajuan permohonan sehingga gugatan tersebut tidak dapat diterima MK.

\section{Kesimpulan}

Terkait pasangan calon tunggal pilkada kabupaten Pati, regulasi memberikan kesempatan lebih luas bagi pengajuan calon dari partai politik atau gabungan partai politik dalam masa perpanjangan pendaftaran. Penundaan pelaksanaan tahapan dan penundaan pilkada yang dilakukan sebanyak dua kali, berdasarkan regulasi yang berlaku memberikan keuntungan bagi pasangan calon yang berasal dari gabungan partai politik. Pendaftaran pun hanya dapat dilakukan oleh pasangan calon yang didukung oleh gabungan partai politik, tidak ada pendaftar dari pasangan calon perseorangan. Struktur regulasi tersebut tidak mencerminkan sebuah kontestasi (uncontested) karena hanya menguntungkan salah satu pihak, yaitu pasangan calon yang didukung oleh gabungan partai politik. Implikasi yang timbul akibat regulasi tersebut, memperkuat kontestasi pilkada bagi calon tunggal dalam pilkada kabupaten Pati.

Menguatnya calon tunggal dalam pilkada kabupaten Pati bukan berarti mutlak langsung memenangkan satu-satunya pasangan calon, Haryanto-Saiful Arifin. Kemunculan GERAM Pati menjadi lawan baru dalam kontestasi pilkada kabupaten Pati. Bagi masing-masing pihak yang berkontestasi hakekatnya didukung regulasi yang berlaku sama, khususnya dalam aturan mengenai kampanye. Selama berkontestasi, GERAM Pati telah melakukan kampanye yang bertujuan untuk menggalang dukungan terhadap kotak kosong.

Pembahasan sebelumnya menyebutkan bahwa GERAM Pati melakukan gerakan politik mendukung kotak kosong melalui kampanye dan sosialisasi yang dimulai dari media sosial hingga media 
cetak dalam bentuk baliho dan selebaran hingga akhirnya mengajukan gugatan hasil pilkada ke Mahkamah Konstitusi. Namun, kampanye dan sosialisasi GERAM Pati pada praktiknya tidak diatur dalam regulasi tentang pilkada, karena aturan tersebut hanya ditujukan bagi pasangan calon dari partai politik atau gabungan partai politik. Bentuk kampanye dan sosialisasi bagi pendukung kotak kosong tidak diatur dengan jelas sehingga menguntungkan bagi pasangan calon tunggal untuk lebih banyak menggalang dukungan.

Meskipun telah melibatkan relawan dalam kampanye, upaya GERAM Pati sebagai pendukung kotak kosong tidak mendapat ruang dalam regulasi yang berlaku. Sehingga perwujudan dukungan civil society melalui GERAM Pati tidak diberikan ruang yang sama dalam kontestasi pilkada. Pasca kemenangan pasangan calon tunggal Haryanto-Saiful Arifin, GERAM Pati mengajukan gugatan hasil pilkada ke Mahkamah Konstitusi, namun upaya tersebut mengalami kegagalan. Penyebab kegagalan paling utama untuk dicermati adalah tidak adanya pengakuan dan pemberian ruang bagi GERAM Pati untuk melakukan gugatan hasil pilkada. Pelaksanaan pilkada kabupaten Pati antara pasangan calon tunggal dan kotak kosong bukan sebuah kontestasi (uncontested), karena infrastruktur regulasi yang dibangun cenderung memberi kemudahan pasangan calon tunggal untuk menang.

Hasil penelitian ini menyimpulkan bahwa upaya yang dilakukan GERAM Pati dalam memenangkan kontestasi pilkada kabupaten Pati mengalami kegagalan. Meskipun GERAM Pati telah melakukan kampanye hingga gugatan terhadap hasil pilkada, namun upaya tersebut merupakan hal yang sia-sia. Mekanisme teknis dari regulasi yang diatur lebih menguntungkan bagi pasangan calon tunggal untuk memenangkan kontestasi pilkada. Regulasi memang mengatur pelaksanaan pilkada sebagai sebuah kontestasi (contested election) antara pasangan calon tunggal dan kotak kosong. Tetapi, infrastruktur regulasi yang dibangun tidak memberikan ruang yang sama bagi 
perwujudan civil society-GERAM Pati-untuk menggalang dukungan bagi kotak kosong melalui kampanye dan penyelesaian sengketa hasil pilkada calon tunggal. Hal tersebut tidak mencerminkan kontestasi sebuah pemilihan untuk mencapai demokrasi (uncontested democracy). Oleh karena itu, tulisan ini memandang penting untuk mengakomodir keterlibatan civil society melalui regulasi dalam kampanye dan penyelesaian sengketa hasil pilkada.

\section{Referensi}

Abhan, Asep Mufti dan Achwan. (2017). Pasangan Calon Melawan Kolom Kosong. Potret Pemilihan Bupati dan Wakil Bupati Pati Tahun 2017. Semarang: Rafi Sarana Perkasa.

Budiman, A. (2018). Kontribusi Masyarakat Sipil di Tahun Politik. Disampaikan dalam Kuliah Umum S2 Tata Kelola Pemilu di Universitas Gadjah Mada. Yogyakarta: Komisi Pemilihan Umum.

Dahl, R. A. (2001). Perihal Demokrasi: Menjelajahi Teori dan Praktek Demokrasi Secara

Singkat. (penerj. Rahmat Zainuddin). Jakarta: Yayasan Obor Indonesia.

Darmawan, Ikhsan. (2017). Peran dan Strategi Kelompok "Kotak Kosong" dalam Pilkada Calon Tunggal Kabupaten Pati Tahun 2017: Studi Pendahuluan. Jurnal Wacana Politik, Vol. 2, No. 1.

Hadiwijoyo, S. S. (2012). Negara, Demokrasi, dan Civil Society. Yogyakarta: Graha Ilmu.

Hikam, Muhammad AS. (1996). Demokrasi dan Civil Society. Jakarta: LP3S. 
Hikmania, Y. S. (2018). Pergulatan Konsep Contested Election dan Uncontested Election (Studi Kasus Pilkada Kabupaten Pati Tahun 2017). Tesis. Tidak Diterbitkan. Fakultas Ilmu Sosial dan Ilmu Politik. Yogyakarta: Universitas Gadjah Mada.

Idhom, A. M. (2017). Politik. Https://Tirto.Id/Meskikalah-SuaraKotak-Kosong-Signifikan-Di-Pati-Cjga. Dipetik 24 Maret 2018, dari tirto.id.

Keputusan KPU Kabupaten Pati Nomor 17/Kpts-PILBUP/KPUkab-012.329311/2016 tentang Pedoman Teknis Pencalonan Pemilihan Bupati dan Wakil Bupati Pati Tahun 2017.

KPU Kabupaten Pati. (2017). Jawaban Termohon dalam Perkara Nomor 41/PHP.BUPXV/2017 yang Dimohonkan oleh GERAM Pati. Surat KPU Kabupaten Pati.

Krjogja. (2017). Pilkada Pati, Muhammadiyah Imbau Warga Tak "Golput". Diambil kembali dari krjogja.com: http://krjogja.com/web/news/read/22537/ home3.html, diakses tanggal 1 Juni 2018.

Lay, C., et. al. (2017). The Rise of Uncontested Elections n Indonesia: Case Studies of Pati and Jayapura. Contemporary Southeast Asia: A Journal of International and Strategic Affairs, Volume 39, Number 3, 427-448.

Mahkamah Konstitusi Republik Indonesia. (2017). Putusan Nomor 41/PHP.BUP-XV|2017. Jakarta: Mahkamah Konstitusi Republik Indonesia.

Peraturan KPU Nomor Nomor 14. (2015). Pemilihan Gubernur dan Wakil Gubernur, Bupati dan Wakil Bupati, danlatau Walikota dan Wakil Walikota dengan Satu Pasangan Calon. 
Tempo. (2017). NU Jawa Tengah Terbitkan Fatwa Calon Tunggal di Pilkada. Diambil kembali 13 Februari 2017 dari nasional.tempo. co: https://nasional.tempo.co/read/845911/ nu-jawa-tengahterbitkan-fatwa-calon-tunggal-di-pilkada.

Torres, L. E., \& Diaz, E. C. (2015). Electoral Governance: More Than Just Electoral Administration. Mexican Review Law, Volume VIII, New Series Number 1, 33-46.

Undang-Undang Nomor 10. (2016). Perubahan Kedua atas UndangUndang Nomor 1 Tahun 2015 tentang Penetapan Peraturan Pemerintah Pengganti Undang-Undang Nomor 1 Tahun 2014 tentang Pemilihan Gubernur, Bupati, dan Walikota menjadi Undang-Undang. 